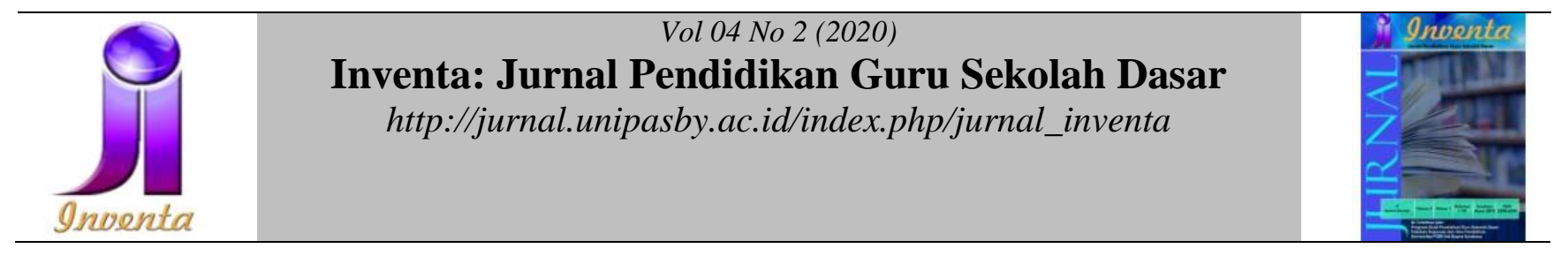

\title{
Analisis Dampak Game Online Mobile Legend Pada Anak Usia Sekolah Dasar Di Desa Junjung Kecamatan Sumbergempol Kabupaten Tulungagung
}

\author{
Nugrananda Janttaka ${ }^{1)}$, Wahyu Juniarta ${ }^{2)}$ \\ Universitas Bhinneka PGRI (UBHI) Tulungagung
}

Corresponding author email: nugra1515@gmail.com

\begin{tabular}{ll}
\hline Kata Kunci: & Abstrak \\
Game Online, Mobile & Penelitian ini bertujuan untuk untuk mendeskripsikan dan menganalisis \\
Legend, Sekolah Dasar & dampak game online mobile legend pada anak usia sekolah dasar di desa \\
& junjung kecamatan sumbergempol. Untuk mencapai tujuan tersebut \\
& digunakan penelitian kualitatif dengan pendekatan penelitian fenomenologi. \\
& Instrumen yang digunakan yaitu dokumentasi, wawancara, dan observasi. \\
& Hasil dari analisis data penelitian diatas menunjukan bahwa anak-anak yang \\
& memiliki permasalahan berupa dampak negatif yang ditimbulkan oleh game \\
& online Mobile legend adalah B I, BA, FE dan NA mereka berempat \\
& memenuhi seluruh indikator berupa kecanduan bermain game, terisolasi \\
& dengan lingkungan sekitar, gangguan psikologis, permasalahan mental seperti \\
& mudah emosi. Adapun dampak positinya dari ketujuh anak tesrsebut adalah \\
& mengenal perkembangan teknologi serta memahami aturan yang berlaku, \\
& melatih perkembangan motorik dan menambah penguasaan kosakata asing.
\end{tabular}

\begin{tabular}{ll}
\hline Keyword: & \multicolumn{1}{c}{ Abstract } \\
$\begin{array}{l}\text { Online Game, Mobile } \\
\text { legend, Elementary }\end{array}$ & This study aims to describe and analyze the impact of legendary online \\
School & mobile games on elementary school age children in the village of Junjung, \\
& Sumbergempol. To achieve these objectives used educational research with \\
qualitative research types with phenomenological research approaches. The & instrument used are document, interview and observation. The results of the \\
analysis of the research data above show that the children who have problems & caused by the legendary Mobile online game are BI, BA, FE and NA, they all \\
& meet all of these indicators because they are 4 who often play the Mobile \\
& Legend online game,has no interaction with peers and neighbours, they have \\
& a physchological disorder anad mental illness. The Positive impact of online \\
& game are got to know of tecnologhy, understand rules of technologhy, \\
& increase motoric and new vocabulary in English.
\end{tabular}




\section{Pendahuluan}

Game online atau sering disebut online games adalah sebuah permainan (games) yang dimainkan di dalam suatu jaringan (baik LAN maupun Internet). Game online sendiri tidak pernah lepas dari perkembangan teknologi komputer dan jaringan komputer itu sendiri, karena game tersebut mempunyai spesifikasi yang harus dimiliki komputer maupun jaringannya. Istilah game disini merupakan permainan elektronik yang menggunakan media komputer atau mesin-mesin konsol. Industri game juga sudah merambah ke berbagai negara di dunia termasuk negara-negara berkembang. Game mulai populer ke seluruh dunia dimulai dengan populernya barbagai game di Amerika pada era 70 -an dan mulai berkembang ke berbagai negara di awal tahun 80-an. Menurut Liga game, game online muncul pada tahun 2001, dimulai dengan masuknya Nexia Online. (Kompasiana, 2020).

Game online adalah suatu permainan yang permainannya terdapat tantangantantangan yang dapat membuat pemainnya menjadi kecanduan untuk terus memainkannya dan apabila sudah menjadi kebiasaan maka akan sulit untuk berhenti dan menjadikan pemainnya lupa dengan waktu, kemunculan game online yang sejak awal kemunculannya, terus dan semakin berkembang dan beraneka ragam jenisnya, meliputi nitendo, sega, dan online game, dan yang sedang trend beberapa tahun belakangan ini terutama dikalangan ini terutama dikalangan remaja yaitu online game, online game adalah permainan yang dimainkan secara online via internet (Young, 2009). Berdasarkan penelitian yang dilakukan oleh Danforth (dalam Nita 2014, hal.3) "frekuensi bermain yang terlalu sering akan mengacaukan kehidupan sehari-hari. Masalah ini bisa mengkhawatirkan jika tidak ada kontrol diri untuk bisa membatasi dari game tersebut."

Penelitian yang dilakukan pada tahun 2008 oleh seorang pakar adiksi video game di Amerika, Mark Griffiths dari Nowingham Trent University, pada anak usia awal belasan tahun menemukan hampir sepertiganya bermain online game setiap hari, "yang lebih mengkhawatirkan sekitar 7\%-nya bermain paling sedikit selama 30 jam per minggu." Menurut Griffiths (2000) betapa besar dampak jangka panjang dari kegiatan yang menghabiskan waktu luang lebih dari 30 jam per minggu, yaitu perkembangan aspek pendidikan, kesehatan dan sosial remaja. Penelitian di Amerika Serikat pada tahun 1999, sebagaimana dikutip majalah monitor (2003), 
mengungkapkan anak berusia 12-18 tahun rata-rata menghabiskan waktu lima setengah jam dirumah dengan menonton TV, memainkan video game, menjelajahi internet. Banyaknya informasi buruk yang membanjiri internet juga salah satu ancaman berbahaya bagi anak.

Game online tentunya juga pasti memiliki sisi negatifnya menurut Wijiarti (2016: 7) Dampak negatif bermain game online adalah menggunakan istilah negatif tertentu untuk menghina gamer lainnya, banyaknya istilah-istilah yang hanya gamers lah yang mengetahui maksud dan istilah yang digunakan kebanyakan ada unsur untuk menghina para pemain lain di game online yang sama. Berdasarkan pengertian diatas maka dampak negatif yang dirasakan oleh para subyek ini juga menjadi salah satu dampak dari bermain game online dimana para pemain akan terganggu atau malah sebaliknya terbiasa dengan kosakata kasar yang diperoleh pada saat permainan di mulai, kebanyakan gamers saat bermain game online akan terbiasa dengan yang namanya identik kosakata baru atau kebiasaan baru yang lama-kelamaan terkenal menghina dan menghakimi dikalangan para pemain game itu sendiri, selainitu dampak yang ditimbulkan oleh game online mobile legend bisa menyebabkan anak menjadi malas belajar karena pada dasarnya game online itu memberikan dampak pada perilaku menunda pekerjaan pada anak. Berdasarkan pengamatan awal yang peneliti peroleh yaitu anak-anak yang berada di Desa Junjung Kecamatan Sumbergempol tidak bisa terlepas dari telepon selulernya, baik itu di rumah, ataupun di luar rumah saat mereka bermain dengan temannya hal ini merupakan dampak yang dituimbulkanoleh kegiatan bermain game online Mobile Legend. Mereka kerap menghabiskan waktunya berjam-jam hanya untuk bermain game online Mobile Legend, bahkan mereka akan marah saat ada orang yang mengganggu permainan mereka dan tak segan untuk melawan meskipun yang mengganggunya usianya berada di atas mereka. alasan kenapa peneliti mengambil anak-anak di Desa Junjung Kecamatan Sumbergempol sebagai responden karena, Ada beberapa anak-anak yang bermain game online Mobile Legend dengan durasi waktu yang sangat lama bahkan mereka bersedia membagi sambungan koneksi internet kepada anak lainnya di tempat biasa mereka berkumpul hanya untuk bermain bareng game online Mobile Legend bersama-sama dan membentuk sebuah tim di dalam permainan tersebut. Adapun tujuan dari penelitian ini adalah untuk 
mendeskripsikan mengenai dampak bermain Game Online Mobile Legend pada anak usia sekolah dasar di Desa Junjung Kecamatan Sumbergempol.

\section{Metode Penelitian}

Jenis penelitian yang dilakukan adalah penelitian kualitatif. Penelitian kualitatif merupakan suatu metode penelitian yang berlandaskan pada filsafat postpositivisme atau enterpretif, digunakan untuk meneliti pada kondisi obyek yang alamiah, dimana penelitian peneliti adalah sebagai instrumen kunci (Sugiyono, 2018, hal.9). Pendekatan penelitian yang digunakan adalah fenomenologis. Pendekatan fenomenologi berhubungan dengan pemahaman tentang bagaimana keseharian, dunia intersubyektif (dunia kehidupan). Fenomenologi bertujuan untuk menginterpretasikan tindakan sosial kita dan orang lain sebagai sebuah yang bermakna (dimaknai) serta dapat merekonstruksi kembali turunan makna (makna yang digunakan saat berikutnya) dari tindakan yang bermakna pada komunikasi intersubjektif individu dalam dunia kehidupan sosial. (Rini Sudarmanti, 2005). Subjek penelitian merupakan pihak yang dipilih untuk dijadikan sampel dalam sebuah penelitian. Arikunto (2013) menyatakan bahwa subjek penelitian adalah benda, hal atau orang tempat data untuk variabel penelitian yang dipermasalahkan melekat. Subjek dalam penelitian ini anak-anak yang berusia Sekolah Dasar yang bermain Game online Mobile Legend yang berjumlah 7 siswa. Adapun Instrument dalam penelitian ini adalah:

1. Pedoman Wawancara

Pedoman wawancara digunakan untuk memperoleh data secara langsung dari informan. Peneliti memilih jenis wawancara terstruktur. Peneliti membuat pedoman wawancara sebelum kegiatan wawancara dilaksanakan hal ini bertujuan untuk menentukan topik bahasan. Kegiatan wawancara bertujuan untuk mengetahui. Pedoman untuk wawancara tercantum dalam lampiran lembar wawancara.

\section{Kisi-Kisi Pedoman Wawancara Anak}

\begin{tabular}{|c|l|l|l|}
\hline $\mathbf{N}$ & Indikator & \multicolumn{1}{c|}{$\begin{array}{c}\text { Jabaran } \\
\text { Indikator }\end{array}$} & \multicolumn{1}{c|}{ Pertanyaan } \\
\hline $\mathbf{1 .}$ & $\begin{array}{l}\text { Mengenal } \\
\text { Dunia } \\
\text { Teknologi? }\end{array}$ & $\begin{array}{l}\text { Peneliti } \\
\text { menanyakan } \\
\text { apakah meraka } \\
\text { memahami } \\
\text { perkembangan } \\
\text { teknologi? }\end{array}$ & $\begin{array}{l}\text { 1.Apakah kamu } \\
\text { memiliki akun email? } \\
\text { 2. Apakah kamu } \\
\text { menguasi microsoft } \\
\text { office? }\end{array}$ \\
\hline $\mathbf{2 .}$ & $\begin{array}{l}\text { Memahami } \\
\text { aturan yang } \\
\text { berlaku } \\
\text { (dalam dunia } \\
\text { teknologi) }\end{array}$ & $\begin{array}{l}\text { Peneliti } \\
\text { menanyakan } \\
\text { apakah merasa } \\
\text { menguasai } \\
\text { langkah-langkah } \\
\text { atau tahapan } \\
\text { dalam membuat } \\
\text { akun atau } \\
\text { langkah-langkah }\end{array}$ & $\begin{array}{l}\text { 3. apakah kamu } \\
\text { paham langkah- } \\
\text { langkah dalam } \\
\text { membuat akun game? }\end{array}$ \\
& $\begin{array}{l}\text { anakah kamu } \\
\text { pernah curang dalam } \\
\text { melakukan permainan } \\
\text { game? }\end{array}$ \\
\hline
\end{tabular}




\begin{tabular}{|c|c|c|c|}
\hline & & $\begin{array}{l}\text { dalam } \\
\text { memproses } \\
\text { aplikasi? }\end{array}$ & \\
\hline 3. & $\begin{array}{l}\text { Melatih } \\
\text { Perkembanga } \\
\text { n Motorik }\end{array}$ & $\begin{array}{l}\text { Peneliti } \\
\text { menanyakan } \\
\text { apakah mereka } \\
\text { memilki } \\
\text { perkembangan } \\
\text { motorik yang } \\
\text { sudah sesuai } \\
\text { dengan usianya }\end{array}$ & $\begin{array}{l}\text { 5. Apakah kamu } \\
\text { dapat membuat } \\
\text { simpul tali pada } \\
\text { sepatumu? } \\
\text { 6. Apakah kamu bisa } \\
\text { melempar dan } \\
\text { menangkap bola } \\
\text { menggunakan satu } \\
\text { tangan? }\end{array}$ \\
\hline 4. & $\begin{array}{l}\text { Menambah } \\
\text { kosakata } \\
\text { bahasa asing }\end{array}$ & $\begin{array}{l}\text { Peneliti } \\
\text { menanyakan } \\
\text { apakah mereka } \\
\text { memahami } \\
\text { bahasa asing } \\
\text { yan terdapat } \\
\text { dalam sebuah } \\
\text { game? }\end{array}$ & $\begin{array}{l}\text { 7. Apakah kamu } \\
\text { memahami arti } \\
\text { bahasa asing dalam } \\
\text { permaian game } \\
\text { mobile legend? } \\
\text { 8. Dari mana kamu } \\
\text { memahami arti kata- } \\
\text { kata asing tersebut? }\end{array}$ \\
\hline 5. & $\begin{array}{l}\text { Menimbulkan } \\
\text { efek } \\
\text { kecanduan } \\
\text { bermain game }\end{array}$ & $\begin{array}{l}\text { Peneliti } \\
\text { menanyakan } \\
\text { seberapa sering } \\
\text { mereka bermain } \\
\text { game? }\end{array}$ & $\begin{array}{l}\text { 9. Dalam sehari kamu } \\
\text { bisa bermain mobile } \\
\text { legend berapa jam? } \\
\text { 10. Bagaimana } \\
\text { perasaanmu jika tidak } \\
\text { bermain mobile legen } \\
\text { dalam beberapa jam } \\
\text { saja? }\end{array}$ \\
\hline 6. & $\begin{array}{l}\text { Terisolir } \\
\text { dalam } \\
\text { lingkungan } \\
\text { sekitar }\end{array}$ & $\begin{array}{l}\text { Peneliti } \\
\text { menanyakan } \\
\text { hubungan } \\
\text { mereka dengan } \\
\text { teman } \\
\text { sebanyanya dan } \\
\text { lingkungan } \\
\text { sekitar? }\end{array}$ & $\begin{array}{l}\text { 11. Apakah kamu } \\
\text { sering berkomunikasi } \\
\text { dengan teman } \\
\text { sebayamu? } \\
\text { 12. Apakah kamu } \\
\text { mengenal tetangga di } \\
\text { sekitarmu? }\end{array}$ \\
\hline 7. & $\begin{array}{l}\text { Gangguan } \\
\text { Psikologis }\end{array}$ & $\begin{array}{l}\text { Peneliti } \\
\text { menanyakan efek } \\
\text { psikologis bagi } \\
\text { mereka yang } \\
\text { bermain mobile } \\
\text { legend }\end{array}$ & $\begin{array}{l}\text { 13. Apakah kamu } \\
\text { sering melamun game } \\
\text { mobile legend saat } \\
\text { sedang belajar? } \\
\text { 14. Apakah kamu } \\
\text { selalu menghayalkan } \\
\text { karakter dalam game } \\
\text { mobile legend? }\end{array}$ \\
\hline 8. & $\begin{array}{l}\text { Mengalami } \\
\text { masalah } \\
\text { mental }\end{array}$ & $\begin{array}{l}\text { Peneliti } \\
\text { menanyakan } \\
\text { seberapa besar } \\
\text { efek mobile } \\
\text { legend bagi } \\
\text { kesehatan mental } \\
\text { mereka }\end{array}$ & $\begin{array}{l}\text { 15. Apakah kamu sring } \\
\text { meresa emosi ketika } \\
\text { kalah dalam main } \\
\text { game? } \\
\text { 16. Apakah kamu } \\
\text { mudah merasa depresi } \\
\text { ketika memiliki } \\
\text { masalah, dan selalu } \\
\text { melarikan diri untuk } \\
\text { bermain game? }\end{array}$ \\
\hline 9. & $\begin{array}{l}\text { Menurunkan } \\
\text { Kesehatan } \\
\text { mata }\end{array}$ & $\begin{array}{l}\text { Peneliti } \\
\text { menanyakan } \\
\text { seberapa besar } \\
\text { tingkat } \\
\text { ketajaman mata } \\
\text { (visus) mereka }\end{array}$ & $\begin{array}{l}\text { 17. apakah sehabis } \\
\text { main game mobile } \\
\text { legend mata kamu } \\
\text { sering kabur? } \\
\text { 18. Bisakah kamu } \\
\text { membaca tulisan yang } \\
\text { saya tunjuk? }\end{array}$ \\
\hline
\end{tabular}

\section{Pedoman Observasi}

\begin{tabular}{|l|l|l|l|}
\hline No & Indikator & \multicolumn{2}{|c|}{ Yasil Pengamatan } \\
\hline 1 & Mengenal dunia teknolgi & Tidak \\
\hline 2 & $\begin{array}{l}\text { Memahami aturan yang } \\
\text { berlaku }\end{array}$ & \\
\hline 3 & $\begin{array}{l}\text { Melatih perkembangan } \\
\text { motorik }\end{array}$ & & \\
\hline 4 & $\begin{array}{l}\text { Menambah kosakata } \\
\text { bahasa asing }\end{array}$ & & \\
\hline 5 & $\begin{array}{l}\text { Menimbulkan efek } \\
\text { kecanduan }\end{array}$ & & \\
\hline 6 & Terisolir dari lingkungan & & \\
sekitar & Gangguan Psikologis & & \\
\hline 7 & Mengalami masalah & & \\
\hline 8 & mental & & \\
\hline
\end{tabular}

\section{Dokumentasi}

Menurut Sugiyono (2016 :

"Dokumentasi merupakan

catatan peristiwa yang sudah berlalu.

Dokumentasi bias berbentuk tulisan,

gambar atau karya-karya

monumental dari seseorang”.

Dokumentasi dalam penelitian ini

berupa gambar-gambar yang peneliti 
ambil ketika melakukan observasi dan wawancara.

\section{Hasil Penelitian}

Peneliti telah melakukan wawancara terhadap tujuh anak usia sekolah dasar di desa Junjung yaitu "BI", "BA", "FE", "NA", "RA", "RI" dan "WI" . Wawancara yang peneliti berikan kepada mereka bertujuan untuk mendeskripsikan dampak game online mobile legend pada anak usia sekolah dasar di desa Junjung Kecamatan Sumbergempol. Adapun kesimpulan hasil wawancara sebagai berikut:

\begin{tabular}{|c|c|}
\hline Pertanyaan & Jawaban Siswa \\
\hline $\begin{array}{l}\text { Apakah kamu memiliki } \\
\text { akun email? }\end{array}$ & $\begin{array}{l}\text { lya saya memiliki akun } \\
\text { email Pak, jadi ketujuh } \\
\text { siswa tersebut memilik } \\
\text { akun email. }\end{array}$ \\
\hline $\begin{array}{l}\text { Apakah kamu menguasai } \\
\text { Microsoft Office (terutama } \\
\text { word)? }\end{array}$ & $\begin{array}{l}\text { lya saya sudah terbiasa } \\
\text { mengetik menggunakan } \\
\text { computer di warnet, dan } \\
\text { jugar mengetik } \\
\text { menggunakan laptop } \\
\text { kakak atau ayah ibunya. }\end{array}$ \\
\hline $\begin{array}{lrr}\text { Apakah kamu } & \text { paham } \\
\text { langkah angkah } & \text { dalam } \\
\text { membuat akun } & \text { game } \\
\text { mobile legend? } & \end{array}$ & $\begin{array}{l}\text { lya. Tentu kami bisa, } \\
\text { tinggal login saja seperti } \\
\text { biasa dan dikaitkan } \\
\text { dengan gmail atau fb. } \\
\text { Jadi mereka semua bisa } \\
\text { login dengan lancar }\end{array}$ \\
\hline $\begin{array}{l}\text { Apakah kamu bisa menali } \\
\text { sepatu sendiri } \\
\text { (contohperkembangan } \\
\text { motorik anak di luar } \\
\text { permainan game)? }\end{array}$ & $\begin{array}{l}\text { lya pak, ini kami } \\
\text { contohkan, sudah bisa } \\
\text { sejak dulu. Mereka } \\
\text { bertujuh mencontohkan } \\
\text { bagaimana menali } \\
\text { sepatu. }\end{array}$ \\
\hline $\begin{array}{l}\text { Apakah kamu memahami } \\
\text { kata-kata dalam bahasa } \\
\text { inggris di game mobile } \\
\text { legend? }\end{array}$ & $\begin{array}{l}\text { lya. Pertama-tama kami } \\
\text { belum paham saat } \\
\text { memainkannya, setelah } \\
\text { sering paham dan juga } \\
\text { hapal }\end{array}$ \\
\hline $\begin{array}{l}\text { Dari mana kamu paham } \\
\text { kata-kata istilah asing } \\
\text { dalam game tersebut? }\end{array}$ & $\begin{array}{lrr}\text { Kami } & \text { bertanya } & \text { kepada } \\
\text { orang } & \text { yang } & \text { lebih tua } \\
\text { serta } & \text { kami } & \text { mencari } \\
\text { artinya } & \text { di } & \text { google }\end{array}$ \\
\hline
\end{tabular}

\begin{tabular}{|c|c|}
\hline & translate \\
\hline $\begin{array}{l}\text { Seberapa sering kamu main } \\
\text { game mobile legend dalam } \\
\text { sehari? }\end{array}$ & $\begin{array}{l}\text { Dari ketujuh anak } \\
\text { tersebut, empat anak } \\
\text { memainkan mobile } \\
\text { legend lebih dari } 8 \text { jam, } \\
\text { sedangkan tiga yang } \\
\text { lainya hanya 3-4 jam saja }\end{array}$ \\
\hline $\begin{array}{l}\text { Apakah kamu sering } \\
\text { berkomunikasi dengan } \\
\text { teman sebayamu, atau } \\
\text { hanya main game saja } \\
\text { tanpa ngobrol? }\end{array}$ & $\begin{array}{l}\text { Dari ketujuh anak } \\
\text { tersebut, empat anak } \\
\text { memainkan mobile } \\
\text { legend dan jarang sekali } \\
\text { berkomunikasi dengan } \\
\text { teman sebaya, } \\
\text { sedangkan tiga yang } \\
\text { lainya hanya memainkan } \\
\text { game ketika senggang } \\
\text { saja }\end{array}$ \\
\hline $\begin{array}{llr}\text { Apakah kamu } & \text { sering } \\
\text { melamunkan game } & \text { mobile } \\
\text { legend ketika } & \text { sedang } \\
\text { belajar? } & & \end{array}$ & $\begin{array}{ll}\text { Dari ketujuh anak } & \text { anak } \\
\text { tersebut, empat } & \text { mobile } \\
\text { memainkan } & \text { sekali } \\
\text { legend dan sering } & \text { game } \\
\text { melamunkan } & \\
\text { moble legend } & \\
\end{array}$ \\
\hline $\begin{array}{l}\text { Apakah kamu pernah } \\
\text { menghayal jadi karakter } \\
\text { yang ada di mobile legend ? }\end{array}$ & $\begin{array}{l}\text { Ketujuh anak tersebut } \\
\text { memiliki kesamaan } \\
\text { pernah menghayal } \\
\text { menjadi hero atau } \\
\text { karakter di mobile legend }\end{array}$ \\
\hline $\begin{array}{l}\text { Apakah kamu } \\
\text { pernahmerasa emosi ketika } \\
\text { kalah saat bermain mobie } \\
\text { legend? }\end{array}$ & $\begin{array}{l}\text { Dari ketujuh anak } \\
\text { tersebut, empat anak } \\
\text { memainkan mobile } \\
\text { legend dengan penuh } \\
\text { luapan emosi ketika } \\
\text { kalah, sedangkan yang } \\
\text { ketiga anak lainnya biasa } \\
\text { saja, karena Cuma untuk } \\
\text { hiburan saja }\end{array}$ \\
\hline $\begin{array}{l}\text { Bisakah kamu membaca } \\
\text { tulisan yang saya tunjuk } \\
\text { (untuk mengukur visus } \\
\text { mata atau jarak apndang } \\
\text { ideal) }\end{array}$ & $\begin{array}{l}\text { Dari ketujuh anak } \\
\text { tersebut, empat anak } \\
\text { yang bermain mobile } \\
\text { legend selama } 8 \text { jam atau } \\
\text { lebih cenderung } \\
\text { kesulitan membaca } \\
\text { tulisan dengan jarak } \\
\text { normal sedangkan yang } \\
\text { lainnya masih bisa } \\
\text { membaca dengan normal }\end{array}$ \\
\hline
\end{tabular}

Dari hasil wawancara yang meliputi dampak positif berupa memahami perkembangan teknologi, ketujuh anak tersebut sangat fasih dan mahir dalam bidang teknologi untuk seusia anak sekolah 
dasar, seperti bisa membuat email sendiri,bisa mengetik Microsoft word, bisa menggunakann google classroom selama pembelajaran di masa pandemi. Dampak positif yang lainnya adalah perkembangan motorik mereka sudah berjalan sesuai dengan tahap perkembangannya, dimana mereka bisa membuat simpul tali sepatu sendiri.Dampak positif lainnya berupa penguasaan kosakata asing mereka secara tidak langsung bertambah, misalnya "buff", "farming" "ganking”, dan sebagainya.

Adapun dampak negatif dari permaian game mobile legend adalah kecanduan seperti yang dialami oleh BI, BA, FE, dan NA yang rata-rata menghabiskan waktu bermain game mobile legend selama 8 jam per hari, sedangkan untuk RA, RI, dan WI hanya menghabiskan waktu sekitar 3 sampai 4 jam saja tiap harinya. Dampak negative lainnya adalah terisolir dengan lingkungan sekitar yaitu teman sebaya dan tetangga. BI, BA, FE, dan NA sangat jarang sekali berkomunikasidengan teman sebayanya maupun tetangganya, beda dengan RA, RI, dan WI yang masih bertegur sapa dengan teman sebaya serta tetangga mereka. Selain itu ada dampak gangguan psikologis berupa sering melamunkan game mobile legend dalam hamper setiap kegiatan, terutama di kala belajar, keempat siswa yakni BI, BA,
FE, dan NA selalu melamunkan game ketika mereka sedang belajar, sehingga mereka tidak pernah fokus dalam belajar. Dampak yang menonjol adalah gangguan mental berupa mudah emosional serta mengeluarkan kata-kata kasar selam bermain game mobile legend, apalagi jika mengalami kekalahan. BI, BA, FE, dan NA sering sekali emosi jika mengalami kekalahan dan itu juga menularkan pada kehidupan pribadi mereka, sehingga sering kali mereka emosi dan berkata-kata kasar, beda dengan RA, RI, dan WI yang melihat kekalahan sebagai bagian dari permainan. Dampak negatif yang terakhir adalah penurunan ketajaman mata yang dialami oleh BI, BA, FE, dan NA, peneliti menunjukkan mereka tulisan dalam jarak normal akan tetapi mereka tidak bisa membacanya secara jelas dan cenderung mendekat pada objek tulisan yang mereka baca. Jadi efek bermain game online yang berlebihan bisa mengakibatkan penurunan ketajaman mata.

Berdasarkan hasil observasi yang peneliti lakukan terhadap tujuh anak usia sekolah dasar terdapat dampak positif dan negatif dari game online mobile legend adalah sebagai berikut:

\begin{tabular}{lll}
\hline Indikator & Hasil Pengamatan \\
\hline Mengenal & dunia & Iya dari ketujuh anak tersebut \\
teknologi & semua melek teknlogi, \\
& memiliki email sendiri, bisa \\
\hline
\end{tabular}




\begin{tabular}{|c|c|}
\hline & $\begin{array}{l}\text { mengoperasikan hp dan } \\
\text { laptop, serta memiliki akun } \\
\text { medsos. }\end{array}$ \\
\hline $\begin{array}{l}\text { Memahami } \\
\text { yang berlaku }\end{array}$ & $\begin{array}{l}\text { lya dari ketujuh anak } \\
\text { tersebut, bisa memahami } \\
\text { aturan yang berlaku dalam } \\
\text { permainan mobile legend, } \\
\text { dan itu memiliki dampak yang } \\
\text { baik dalam kehidupan sehari- } \\
\text { hari, seperti memahami } \\
\text { aturan dalam menggunakan } \\
\text { aplikasi online yang } \\
\text { mendukung pembelajaran. }\end{array}$ \\
\hline $\begin{array}{l}\text { Melatih perkembangan } \\
\text { motorik }\end{array}$ & $\begin{array}{l}\text { lya, mereka memiliki } \\
\text { kemampuan motorik yang } \\
\text { baik. Bisa menali simpul } \\
\text { sepatu,menangkap bola } \\
\text { dengan satu tangan, dan } \\
\text { melakukan apapun kegiatan } \\
\text { motorik sesuai dengan } \\
\text { tahapan usianya }\end{array}$ \\
\hline $\begin{array}{l}\text { Menambah kosakata } \\
\text { asing baru }\end{array}$ & $\begin{array}{l}\text { Tentu saja secara tidak } \\
\text { langsung mereka menguaai } \\
\text { kosakata Bahasa Inngris yang } \\
\text { terdaat dalam mobile legend } \\
\text { seperti "buff", "farming" dsb }\end{array}$ \\
\hline $\begin{array}{l}\text { Menimbulkan } \\
\text { kecanduan }\end{array}$ & $\begin{array}{l}\text { Hanya empat anak yang } \\
\text { mengalami kecanduan, yaitu } \\
\mathrm{BI}, \mathrm{BA}, \mathrm{FE} \text {, dan NA. } \\
\text { Penyebabbnya adalah durasi } \\
\text { bermain yang hamper } 8 \text { jam } \\
\text { sehari }\end{array}$ \\
\hline $\begin{array}{l}\text { Terisolir dari } \\
\text { lingkungan sekitar }\end{array}$ & $\begin{array}{l}\text { Hanya empat anak yang } \\
\text { mengalami kecanduan, yaitu } \\
\text { BI, BA, FE, dan NA. } \\
\text { Penyebabnya adalah sering } \\
\text { mengisolasi diri mereka } \\
\text { sendiri dan enggan melakuka } \\
\text { kntak sosial dengan eman } \\
\text { sebaya maupun tetangga }\end{array}$ \\
\hline Gangguan Psikologis &  \\
\hline $\begin{array}{l}\text { Mengalami } \\
\text { mental }\end{array}$ & $\begin{array}{l}\text { Hanya empat anak yang } \\
\text { mengalami kecanduan, yaitu } \\
\text { BI, BA, FE, dan NA. } \\
\text { Penyebabnya adlah kebiasaan } \\
\text { tidak mengontrol emosi } \\
\text { ketika kalah dalam bermain } \\
\text { game, sehingga } \\
\text { mempengaruhi perilaku pada }\end{array}$ \\
\hline
\end{tabular}

\begin{tabular}{ll}
\hline & kegiatan sehari-hari \\
\hline Menurunkan & Hanya empat anak yang \\
kesehatan mata & mengalami kecanduan, yaitu \\
& BI, BA, FE, dan NA. Mereka \\
& tidak mampu membaca \\
& sesuai jarak yang normal dan \\
& cenderung mendekatkan \\
& pada objek yang mereka \\
& baca. \\
\hline
\end{tabular}

Dari pengamatan yang telah peneliti lakukan selama kurang lebih tiga bulan, terdapat halhal yang perlu digaris bawahi bahwa game online mobie legend tidak hanya memberikan efek negatif saja, melainkan juga memberikan efek positif, yaitu anak usia sekolah dasar di jaman sekarang mereka lebih melek teknologi, mereka sudah bisa menyesuaikan dengan perkembangan jaman dan tidak tertinggal oleh genarasi dari bangsa lain. Efek positif yang kedua adalah membantu perkembangan gerak motorik pada anak usianya, sehingga mereka bisa melakukan gerak motorik kasar dan halus dalam melakukan kegiatan sehari-hari. Dampak yang lainnya adalah menambah kosakata baru dalam bahasa asing yaitu Bahasa Inggris, anak-anak usia sekolah dasar secara tidak langsung menambah kosakata baru dari game yang mereka suka, bisa mobile legend atapun game yang lainnya. Beralih ke dampak negatif, tentu saja ini yang harus dihindari, dari tujuh siswa yang diteliti, keempat nya mengalami efek negatif dari game online mobile legend, 
yaitu kecanduan bermain game dimana BI, BA, FE, dan NA menghabiskan rata-rata 8 jam perhari untuk bermain mobile legend. Dampak negatif lainya adalah terisolirnya mereka dari lingkungan sekitar akibat mereka cenderung bermain sendiri dan kurang adanya interaksi dengan teman sebaya, dari ketujuh anak tersebut, mereka berempat yakni BI, BA, FE, dan NA yang sering menghabiskan waktu bermain mobile legend juga kurang berinterkasi dengan teman sebaya dan lingkungannya. Dampak negatif selanjutnya adalah gangguan psikologis yang dialami BI, BA, FE, dan NA dikarenakan kecanduan sehingga merembet dalam kehidupan mereka sehari-hari, seperti sering melamunkan game mobile legend saat belajar. Dampak negative yang terakhir adalah menurunkan kesehatan mata, sehingga mereka tidak bisa melihat objek tulisan dalam jarak normal, diakibatkan oleh cahaya pada HP yang sering mereka lihat selama kurang lebih 8 jam.

\section{Simpulan}

Berdasarkan hasil penelitian diatas dapat disimpulkan bahwa dampak bermain game mobile legend ada dua yaitu dampak positif dan negatif. Dari tujuh siswa yang diamati oleh peneliti dan berdasarkan hasil wawancara dengan mereka, bahwa dampak negatif game online dialami oleh 4 anak usia sekolah dasar yaitu BI, BA, FE, dan NA, sedangkan untuk ketiga anak lainnya yakni RI, RA, dan WI tidak mengalami dampak negatif dikarenakan mereka bermain game mobile legend sebatas untuk hiburan dalam waktu luang. Adapun dampak positif dialami oleh tujuh anak di desa Junjung Kecamatan Sumbergempol meliputi mengenal dunia teknologi, memahami aturan yang berlaku, melatih perkembangan motorik, dan menambah kosakata baru dalam Bahasa Inggris.

\section{Daftar Pustaka}

Adams, Ernest, and Andrew Rollings. "Game design and development: Fundamentals of game design." New Jersey: Pearse Prentice Hall (2007).

Arikunto, S. (2013). Prosedur Penelitian Suatu Pendekatan Praktik. Jakarta: PT. Rineka Cipta.

Dewi, Puspita Nita (2014) Hubungan Antara Intensitas Bermain Game Online Dengan Interaksi Sosial Remaja. . Jurnal Online Mahasiswa Fakultas Psikologi Universitas Muhammadiyah Surakarta.

Griffiths, M. (2000). "Does Internet and Computer addiction exist? Some casestudy evidence. Cyber Psychology \&Behavior. 3: 211-218.

Khoiriyah, Siti (2019) Dampak Game Online Terhadap Perilaku Remaja Dalam Pelaksanaan Ibadah Shalat Lima Waktu Di Desa Sarangai Kecamatan Katibung Kabupaten Lampung Selatan. SKRIPSI. UIN Raden Intan Lampung. 
Kompasiana (2020) Sejarah Game Online https://www.kompasiana.com/hacko nline88/5dbe9f48097f367b72585eb2 /sejarah-game-online-di-industriandroid

Sugiyono, (2018). Metode Penelitian Kuantitatif, Kualitatif, dan R\&D. Bandung: CV Alfabeta.

Surbakti, K. (2017). Pengaruh Game Online TerhadapRemaja. JurnalCurere| Vol. $01 \mid$ No. $01 \mid$ April 2017| p-ISSN : 2597-9507| e-ISSN: 2597-9515, 01(01), 28-38.

Wijiarti, Della Nur. (2016). Dampak Game Online Terhadap Pembelajaran Bahasa inggris (ditinjau dari persepsi mahasiswa). Manado: UniversitasSam Ratulangi.

Young, K. S. (2009). “Understanding Online Gaming Addiction and Treatment issuesfor adolescents". The American Journal of Family Therapy. 37: 355-372. 